\title{
Detection of Brazilian spotted fever infection by polymerase chain reaction in a patient from the state of São Paulo
}

\section{Elvira Maria Mendes Nascimento, Flávia de Sousa Gehrke***, Rosa Amélia Maldonado**, Silvia Colombo, Luiz Jacintho da Silva*, Teresinha Tizu Sato Schumaker*** ${ }^{+}$}

\begin{abstract}
Laboratório de Rickettsias, Instituto Adolfo Lutz, São Paulo, SP, Brasil *Departamento de Clínica Médica, FCM, Unicamp e Superintendência do Controle de Endemias, Secretaria de Estado da Saúde de São Paulo, São Paulo, SP, Brasil **Dept. of Biological Sciences, University of Texas at EL Paso, TX-79968, US ***Departamento de Parasitologia, Instituto de Ciências Biomédicas, Universidade de São Paulo, Av. Professor Lineu Prestes 1374, 05508-900 São Paulo, SP, Brasil
\end{abstract}

Brazilian spotted fever (BSF) cases have been increasing in the state of São Paulo but no genomic information about local rickettsia isolated from humans has been well documented. We recovered spotted-fever group rickettsiae from a sample of patient blood cultured in Vero cells using the shell vial technique. Rickettsial DNA fragments ( $\mathrm{glt} A, \mathrm{omp} A$, and, omp $B$ genes) were detected, and analysis of the omp $B$ gene base sequences showed identity with the Rickettsia rickettsii $\mathrm{omp} B$ sequence available in the GenBank.

Key words: Brazilian spotted fever - Rickettsia rickettsii - ompB gene

Brazilian spotted fever (BSF) is a rickettsiosis very similar to the North American Rocky Mountain spotted fever (RMSF) caused by Rickettsia rickettsii, which is maintained in nature in a cycle involving ticks and mammals. The initial signs and symptoms of the disease include the sudden onset of fever, headache, and muscle pain, followed by the development of a rash (Lemos et al. 2001). This disease can be difficult to diagnose in its early stages, and without prompt and appropriate treatment it can be fatal.

BSF cases are known to occur in the Southeastern Brazilian states of São Paulo, Minas Gerais, Rio de Janeiro, and Espírito Santo (Sexton et al. 1993, Lemos 2002, Galvão et al. 2003). Although several Ixodid tick species of the genus Amblyomma may be involved in the BSF cycle, A. cajennense is considered the main vector species (Magalhães 1952, Lemos 2002). Isolated reports from areas of the country that are far apart, with differing ecology, suggest that the disease may be more common than is shown by existing data.

In recent years, an upsurge of cases has been recorded in the state of São Paulo, particularly in the Atibaia, Jaguari, and Camanducaia river basins, principally in the Pedreira municipality (Lemos et al. 2001). Increased pressure on the remaining forests and a population growth of the mammalian tick host, the capybara (Hydrocherus hydrocherus), could be causes for the apparent increase in human cases. The majority of studies of $R$. rickettsii characteristics rely

\footnotetext{
Financial support: Fapesp

${ }^{+}$Corresponding author. E-mail: ttsschum@icb.usp.br

Received 22 September 2004

Accepted 14 March 2005
}

on serology and immunostaining of tissues and culture, individually or in combination (Melles et al. 1999, Lemos et al. 2001), but no genomic information about local rickettsia isolated from humans has been well documented. From the ticks A. cajennense and A. cooperi collected in this focus, Spotted Fever Group (SFG) rickettsiae were isolated by culture in Vero cell and confirmed by immunofluorescent antibody assay (Lemos et al. 1996, Nascimento 2003), but none of these studies went as far as species identification.

We report the use of molecular biology methods for the identification of BSF-causing-Rickettsia, in this important Brazilian endemic area. The protocol utilized was approved by the Ethical Committee on Human Experimentation of the Instituto de Ciências Biomédicas (Biomedical Sciences Institute/USP).

The patient was a five-year old boy from Artur Nogueira, a municipality of the state of São Paulo, with history of recent tick exposure. During the course of the disease the patient presented fever, malaise, myalgia, headache, abdominal pain, and maculopapular rash. The blood sample was collected six days after the onset of symptoms in September 1998. The sample clot was diluted to a $10 \%$ suspension in brain heart infusion broth (BHI) and was stored at $-70^{\circ} \mathrm{C}$ in the Laboratory of the Adolfo Lutz Institute (IAL) until the use. For cultures, blood clot aliquots were centrifuged and the supernatant was inoculated in a confluent monolayer of Vero cells on circular slides adapted to the flat-bottomed tubes (shell vials) as previously described (Melles et al.1999). Infection of Vero cells was monitored by immunofluorescence reaction prepared with $R$. rickettsii-positive human serum, which permitted us to observe the presence of fluorescent microorganisms in form of intracellular bacteria (Marrero \& Raoult 1989). Part of the remainder blood clot sample was used for rickettsial gene access. No patient serum was available for serology. 
Prior to DNA extraction through the use of phenol/ phenol-chloroform, the frozen blood clot was incubated at $56^{\circ} \mathrm{C}$ for $2 \mathrm{~h}$ for rickettsiae inactivation (Tzianabos et al. 1989). Rickettsial DNA was detected by polymerase chain reaction (PCR) using previously described conditions (Regnery et al. 1991) and the three sets of primers (GIBCO BRL), RpCs.877p (5'-GGGGGCCTGCTCACGGCGG) and $R p$ Cs.1258n (5'- ATTGCAAAAAGTACAGTGAACA) to amplify a 381-bp fragment of the citrate synthase gene (gltA) of Rickettsia species (Wood et al. 1987); $R r 190.70 \mathrm{p}$ (5'-ATGGCGAATATTTCTCCAAAA) and $R r 190.602 \mathrm{n}$ (5'AGTGCAGCATTCGCTCCCCCT) for a 532-bp fragment of the 190-kDa surface protein gene (ompA) of SFG rickettsia (Regnery et al. 1991); and BG1-21 (5'GGCAATTAATATCGCTGACGG) and BG2-20 (5'- GCA TCTGCACTAGCACTTTC) for a 650-bp fragment of the $120 \mathrm{kDa}$ surface protein gene ( $\mathrm{ompB}$ ) of SFG and Typho Group rickettsiae (Eremeeva et al. 1994). PCR products to be sequenced were cloned into plasmid vector pGEMTEasy (Promega). Escherichia coli strain DH5 $\alpha$ cells were transformed by the method described by Sambrook et al. (1989). The transformants carrying the vector with the DNA insert were screened by color on plates containing $\mathrm{X}-\mathrm{Gal}$, IPTG and ampicilin. The clones were digested with the restriction endonuclease Eco RI. The sequence analysis was carried out using the Thermo Sequenase Fluorescent Labelled Primer Cycle Sequencing kit (Amersham Pharmacia) and an ALF express automatic sequencer (Amersham Pharmacia) with ALFwin 2.1 software. The sequence of both DNA strands was determined twice.

For Southern blot analysis, $10 \mu \mathrm{l}$ of PCR product was separated by electrophoresis on a $2 \%$ agarose gel and transferred to a positively charged nylon membrane (Hybond $\mathrm{N}^{+}$, Amersham-Pharmacia Biotech) (Sambrook et al. 1989). Hybridization and signal detection were performed using the Gene Images labelling and detection kit (Amersham-Pharmacia-Biotech).
The PCR amplification of $381 \mathrm{bp}, 650 \mathrm{bp}$, and $532 \mathrm{bp}$ fragments respectively for $g l t \mathrm{~A}, o m p \mathrm{~B}$, and $o m p \mathrm{~A}$ genes, and the positive hybridization shown in the Southern blot (Figure) confirms the SFG rickettsia propagation through cell Vero culture. The sequence analysis of $о т p \mathrm{~B}$ gene fragment showed $98 \%$ identity with $R$. rickettsii (GenBank access number Gi46939). The GenBank accession number for the partial $\mathrm{omp \textrm {B }}$ reported in this communication is AY751299 (R. rickettsii strain Brazil).

Recently, molecular techniques were used to detect Rickettsia in blood sucking arthropods collected in the BSF transmission foci in the state of São Paulo. The rickettsial gltA gene fragments were detected in A. cooperi, by PCR, and the sequence analyzed showed homology with $R$. belli, a non-pathogenic rickettsia species (Horta 2002, Estrada 2003). The ompA gene of SFG rickettsia was accessed in A. cajennense collected from different localities (Nascimento 2003). R. felis, a pathogenic SFG rickettsia, was detected in Ctenocephalides felis collected from local domestic dogs (Horta 2002). In addition, R. felis was detected in Ctenocephalides fleas (Oliveira et al. 2002) in the state of Minas Gerais, Brazil, employing these same molecular techniques, collected in an area where patients with $R$. felis rickettiosis were reported (Raoult et al. 2001, Galvão et al. 2004). These findings suggest that, although $R$. rickettsii is accepted as a BSF causing agent other rickettsiae species or different $R$. rickettsii variants may be involved, playing roles as yet to be determined.

Based on our present result, we can say that $R$. rickettsii can be one of the etiological agents of BSF in the state of São Paulo and the use of PCR amplification of the $о m p \mathrm{~B}$ gene coupled with partial DNA sequencing can be used as a valuable technique for establishing a definitive diagnosis of BSF during the critical stage. For a better characterization of the BSF agent sequence analysis of the amplified ompA and glt A fragments is in progress.
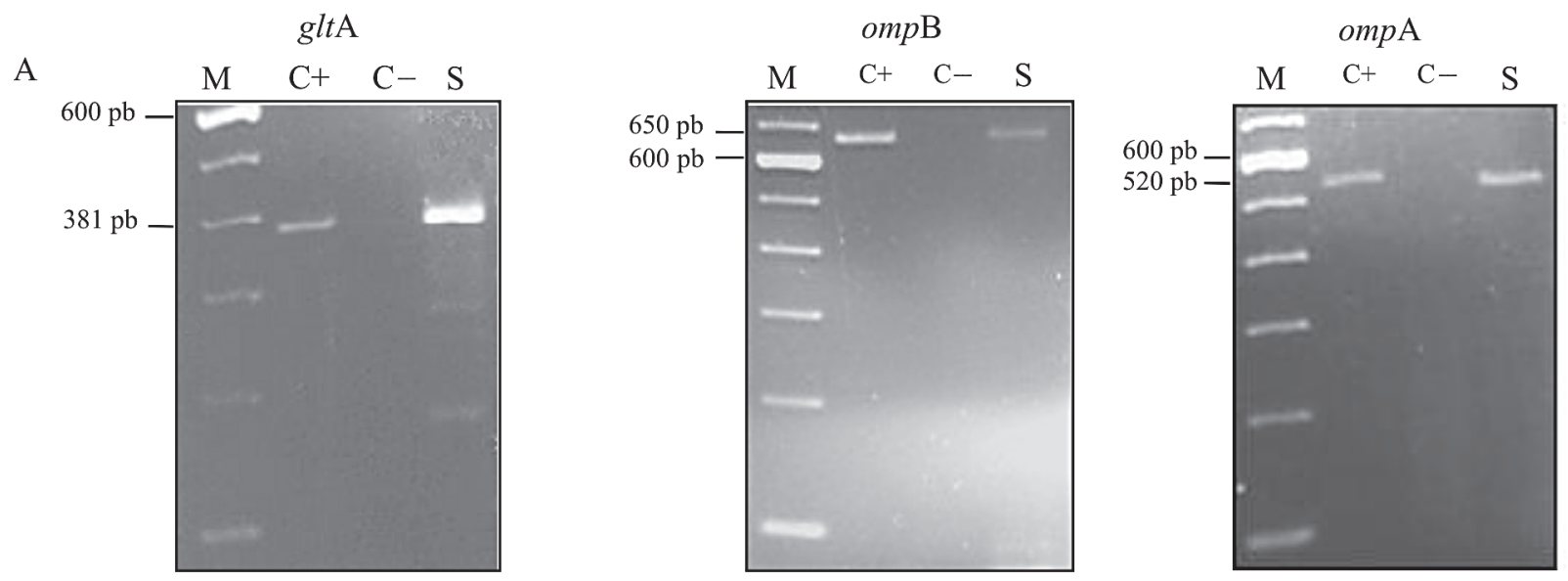

B
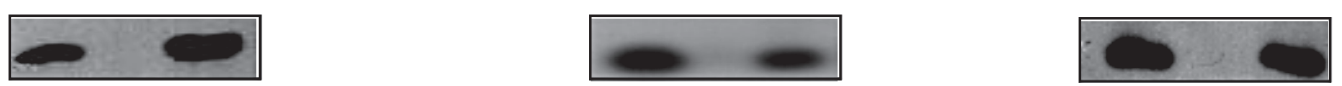

A: polymerase chain reaction of glt A, ompB, and ompA genes from Brazilian patient blood. M: weight molecular 600 base pair; C+: positive control Rickettsia rickettsii, Sheila Smith strain; C-: negative control water; and S: human blood. B: Southern blot analysis of the PCR products, using the fluorescein labelled fragment of glt $\mathrm{A}$, omp $\mathrm{B}$, and ompA genes as probes to their respective blots. 


\section{ACKNOWLEDGEMENTS}

To HHB Melles (IAL/São Paulo) who provided the Rickettsia rickettsii (Sheilla Smith strain) to use as positive control for our experiments.

\section{REFERENCES}

Eremeeva M, Yu X, Raoult D 1994. Differentiation among spotted fever group rickettsiae species by analysis of restriction fragment length polymorphism of PCR-amplified DNA. J Clin Microbiol 32: 803-810.

Estrada DA 2003. Aplicação da Reação em Cadeia pela Polimerase para Detecção de Riquétsias em Carrapatos (Acari: Ixodidae) Coletados no Município de Campinas, $S P$, Thesis, Departamento de Parasitologia, Universidade Estadual de Campinas, Campinas.

Galvão MA, Dumler JS, Mafra CL, Calic SB, Chamone CB, Cesarinho Filho G, Olano JP, Walker DH 2003. Fatal spotted fever rickettsiosis, Minas Gerais, Brazil. Emerg Infect Dis 9: 1402-1405.

Galvão MA, Mafra C, Chamone CB, Calic SB, Zavala-Velazquez JE, Walker DH 2004. Clinical and laboratorial evidence of Rickettsia felis infections in Latin America. Rev Soc Bras Med Trop 37: 238-240.

Horta MC 2002. Pesquisa de Infecção por Riquétsias do Grupo da Febre Maculosa em Humanos, Eqüídeos, Caninos e Diferentes Estádios de Vida de Amblyomma cajennense, Provenientes de uma Área Endêmica do Estado de São Paulo, Thesis, Faculdade de Medicina Veterinária e Zootecnia, Universidade de São Paulo, São Paulo.

Lemos ERS 2002. Rickettsial diseases in Brazil. Virus Reviews and Research 7: 7-16.

Lemos ERS, Alvarenga FBF, Cintra ML, Ramos MC, Paddock CD, Ferebee TL, Zaki SR, Ferreira FCC, Ravagnani RC, Machado RD, Guimarães MAAM, Coura JR 2001. Spotted fever in Brazil: a seroepidemiological study and description of clinical cases in an endemic area in the State of São Paulo. Am J Trop Med Hyg 65: 329-334.

Lemos ERS, Melles HHB, Colombo S, Machado RD, Coura JR, Guimarães MAA, Sanseverino SR, Moura A 1996. Primary isolation of spotted fever group Rickettsiae from Amblyomma cooperi collected from Hydrochaeris hydrochaeris in Brazil. Mem Inst Oswaldo Cruz 91: 273275.
Magalhães O 1952. Contribuição para o Conhecimento da Doença do Grupo Tifo Exantemático, Monog 6, Instituto Oswaldo Cruz, Rio de Janeiro, 968 pp.

Marrero M, Raoult D 1989. Centrifugation-shell vial technique for rapid detection of mediterranean spotted fever rickettsia in blood culture. Am J Trop Med Hyg 40: 197-199.

Melles HHB, Colombo S, Lemos ERS 1999. Isolamento de Rickettsia em cultura de células vero. Rev Soc Bras Med Trop 32: 469-473.

Nascimento EMM 2003. Isolamento e Detecção Molecular de Riquétsias do Grupo da Febre Maculosa, a Partir de Amblyomma cajennense (Fabricius, 1787) e Espécimens Biológicos Humanos, Procedentes de Áreas Endêmicas do Estado de São Paulo, Thesis, Instituto de Ciências Biomédicas, Universidade de São Paulo, São Paulo.

Oliveira RP, Galvão MA, Mafra CL, Chamone CB, Calic SB, Silva SU, Walker DH 2002. Rickettsia felis in Ctenocephalides spp. fleas, Brazil. Emer Infec Dis 8: 317-319.

Raoult D, Scola B, Enea M, Fournier PE, Roux V, Fenollar F, Galvão MA, Lamballerie X 2001. A flea-associated Rickettsia pathogenic for humans. Emer Infec Dis 7: 73-81.

Regnery RL, Spruil CL, Plikaytis BD 1991. Genotypic identification of rickettsiae and estimation of intraspecies sequence divergence for portion of two rickettsial genes. $J$ Bacteriol 173: 1576-1589.

Sambrook J, Fritsch EF, Maniatis T 1989. Molecular Cloning: A Laboratory Manual, 2nd ed., Cold Spring Harbor Laboratory Press, New York.

Sexton DJ, Muniz M, Corey GR, Breitschwerdt EB, Hegarty BC, Dumler S, Walter DH, Pecanha PM, Dietze R 1993. Brazilian spotted fever in Espirito Santo, Brazil: description of a focus of infection in a new endemic region. Am J Top Med Hyg 49: 222-226.

Tzianabos T, Anderson BE, MacDade JE 1989. Detection of Rickettsia rickettsii DNA in clinical specimens by using polymerase chain reaction technology. J Clin Microb 27: 2866-2868.

Wood DO, Williamson LR, Winkler HH, Krause DC 1987. Nucleotide sequence of the Rickettsia prowazekii citrate synthase gene. J Bacteriol 169: 3564-3572. 
